\title{
Twenty years of ethnic-racial relations in the National High School Exam - ENEM (1998-2018)
}

\author{
Tuca Henrique Verçosa Carneiro de Andrade ${ }^{1 *}$; Juceli Gomes de Queiroz ${ }^{2}$; Eduardo Henrique da \\ Silva Melo ${ }^{3}$; Paolla Ribeiro Lima ${ }^{4}$; Pedro Eduardo Santos Silva ${ }^{5}$; Adla Polayne Barbosa da Silva ${ }^{6}$; \\ Renata dos Santos Mélo ${ }^{7}$; Marcos Vinícius Alves Da Silva ${ }^{8}$; Romualdo Arthur Ferreira de Lima ${ }^{9}$; \\ Paulo Manoel da Silva ${ }^{10}$; Elias Ancelmo ${ }^{11}$, Taynara Bezerra dos Santos ${ }^{12}$
}

1 Graduated in History from UFPE and master's degree in Education of the Graduate Program in Education at UFPE

2 Graduating in life sciences from the University Center of Vitória de Santo Antão - UNIVISA

3 Undergraduate degree in Biological Sciences, Federal University of Pernambuco, Academic Center of Vitória

4 Undergraduate degree in Biological Sciences, Federal University of Pernambuco, Academic Center of Vitória

5 Undergraduate degree in Biological Sciences, Federal University of Pernambuco, Academic Center of Vitória

6 Graduating in full degree in biological sciences from the University Center of Vitória de Santo Antão- UNIVISA

7 Graduating in full degree in biological sciences at Federal University of Pernambuco, Academic Center of Vitória

8 Graduate of The Methodology Course of Biological Sciences Teaching of The University Center Leonardo Da Vinci - UNIASSELVI.

9 Graduated in Full Degree in Biological Sciences from the University Center of Vitória de Santo Antão- UNIVISA

10 Graduating in full degree in biological sciences from the University Center of Vitória de Santo Antão- UNIVISA.

11 Graduated in Letters from the University of Pernambuco - UPE, Campus Mata Norte

12 Undergraduate degree in Biological Sciences at Federal University of Pernambuco - UFPE

E-mail adresses: tucavercosa@hotmail.com (Tuca Henrique Verçosa Carneiro de Andrade), Juceligomes1995@gmail.com (Juceli Gomes de Queiroz), Eduardo.henriquem@ufpe.br (Eduardo Henrique da Silva Melo), paolla.lima@ufpe.br (Paolla Ribeiro Lima), Pedroeduardo942@gmail.com (Pedro Eduardo Santos Silva), adlapbs@gmail.com (Adla Polayne Barbosa da Silva), renata.santosmelo@ufpe.br (Renata dos Santos Mélo), vinicius201653@gmail.com (Marcos Vinícius Alves Da Silva), paulomanoe1041@gmail.com (Paulo Manoel da Silva), r.arthur16@gmail.com (Romualdo Arthur Ferreira de Lima), eliasancelmoo19@gmail.com (Elias Ancelmo), taynara.santos@ufpe.br (Taynara Bezerra dos Santos).

${ }^{*}$ Corresponding author

\section{To cite this article:}

Andrade, T.H.V.C.; Queiroz, J.G.; Melo, E.H.S.; Lima, P.R.; Silva, P.E.S.; Silva, A.P.B.; Mélo, R.S.; Silva, M.V.A.; Silva, P.M.; Ancelmo, E.; Santos, T.B. Twenty years of ethnic-racial relations in the National High School Exam - ENEM (1998-2018). International Journal of Sciences. Vol. 2, No. 3, 2021, pp. 45-55. ISSN 2763-5392.

Received: 10 13, 2021; Accepted: 10 14, 2021; Published: 11 03, 2021

\begin{abstract}
The field of education is a field of constant disputes; disputes around educational principles, methodologies, curricula, among others. Increasingly, new subjects begin to emerge in historical narratives (in addition to kings and emperors), with the works of historians, who began to care about ordinary people and not just as the "great" facts and the "great" events. The present work aims to discuss the twenty years of ethnic-racial relations in the National High School Exam - ENEM, from 1998 to 2018. This is a study with data collection from secondary sources, through bibliographic survey in the following databases: Google Academic and Scientific Electronic Library Online (SciELO). The ENEM, created in 1998, until 2009, was directed to evaluate the knowledge and skills of students who had just left high school, aiming to make an evaluation of Brazilian basic education. We analyzed 1069 questions of the ENEM, of which 29 were selected because they contemplate the theme to which we propose to analyze in this work. We believe that the ENEM can also be another strategy for overcoming racism in Brazil to be intensely discussed and promoted in basic education.
\end{abstract}

Keywords: ENEM. Ethnic-racial relations. Racism. 


\section{Introduction}

The field of education is a field of constant disputes; disputes around educational principles, methodologies, curricula, among others. In this sense, the teaching of history is also a field of disputes and these are based on the discoveries/interpretations made by historians who come to school, as a form of systematized knowledge (FONSECA, 2011).

After World War II, history teaching began to gain the function of forming for democracy and tolerance between peoples and nations (LAVILLE, 1999). According to this, a number of historical schools reinforced their questions about the historical narratives in circulation and the "who" these narratives gave voices.

Increasingly, new subjects begin to emerge in historical narratives (in addition to kings and emperors), with the works of historians, who began to care about ordinary people and not just as the "great" facts and the "great" events. This movement was reinforced by a will ingress to selfknowledge and the search for a memory that came from the "minorities", who were silenced by history. That is, social movements began to struggle to "democratize" historical narratives and to give other subjects the participation that was due to them in national history (THOMPSON, 2001).

In this sense, changes in Brazilian historiography began to become sensitive, especially from the 1980 s onto various research themes. The history of slavery, one of the great problems for the national human sciences, went through a series of (re)visits, new narratives were being woven, and understandings about this phenomenon changed radically in the passage of 60 years of research, as we will see in the course of this work (SAVIANI, 2012).

The teaching of history also felt this change, which occurred in the academy, otherwise (SAVIANI, 2012). Knowing that the historical research has launched new questions and has presented new answers on the history of slavery, we seek to discuss how the ENEM, which proposes to bring what is new in scientific and artistic production (ANDRIOLA, 2011, p.116), presented these changes in its versions.

The present work aims to discuss the twenty years of ethnic-racial relations in the National Exam of High School - ENEM, from 1998 to the year 2018.

\section{Methodology}

This is a study with data collection from secondary sources, through a bibliographic survey and based on the experience experienced by the authors at the time of an integrative review.

For the survey of articles in the literature, a search was conducted in the following databases: Google Academic and Scientific Electronic Library Online (SciELO). As an exclusion criterion, articles in English and Spanish were excluded.

\section{Results and Discussion}

\subsection{About the National High School Exam - ENEM}

The National High School Exam was outlined during the government of Fernando Henrique Cardoso, ahead of the Ministry of Education Paulo Renato de Souza, who promoted a series of reforms in education, for example, the National Curriculum Guidelines for High School (DCNEM), the National Curriculum Parameters for High School (PCNEM) and the evaluations: The National Course Exam (Provão), the National Basic Education Assessment System (SAEB) and the National High School Exam (ENEM).

The ENEM, created in 1998, until 2009, was directed to evaluate the knowledge and skills of students who had just left high school, aiming to make an evaluation of Brazilian basic education. The data produced by exam were thought to be comparable, through the performance of the National Institute of Educational Studies and Research Anísio Teixeira - INEP, to educational indexes from other places in the world. In the first years of its implementation, the Exam did not have a massive support of Brazilian students, as it was unknown and would have no practical purposes for the lives of those who left high school (PEROBA, 2017, p.117).

Currently, it is the second largest access exam for in the world, considering that, since 2009, this exam began to replace the main entrance exams that lead to access to Brazilian public higher education. Generally speaking, this change in the meaning and meaning of the exam reverted in its structuring over the years: from 1998 to 2009 (period prior to its "vestibularization") had 63 interdisciplinary questions, distributed without a specific organization by areas of knowledge and an essay; and, from 2009, it began to have 180 questions, distributed in 4 areas of knowledge (Human sciences and their technologies, languages and their technologies, mathematics and their technologies and nature sciences and their technologies), in addition to an essay. For each of these areas of knowledge, the exam presents 45 questions (PEROBA, 2017, p.118).

The part of human sciences and their technologies are divided into four school disciplines, that is: history, geography, philosophy and sociology and, given the high level of interdisciplinarity of the test, it is sometimes quite difficult to separate the questions by specific disciplines.

The ENEM test underwent several transformations to meet changes in society's expectations about education and to achieve one of its purposes that was to become the largest tool for access to higher education in Brazil (DASILVA et al, 2018, p.19-21). Since the 2000s, more and more people have been taking the ENEM test and more higher education institutions use ENEM grades as a reference for their selection processes (WERLE, 2011, p.776). "In 2000, 182 Higher Education Institutions formally demonstrated the use of ENEM results in their selection processes" (BRASIL, 2001 , p. 16), although, only in 2009 , the exam was officially used for this. Currently, 1434 higher education institutions do so in Brazil; more than 30 in Portugal (DASILVA et al, 2018, p.19-21).

This increase in the number of people taking the test occurred due to a series of incentives by the federal government. For example, in 2001, the possibility of exemption from the registration fee was granted to those who were completing high school in a public educational 
institution and to the graduates of the EJA of the year prior to the approval of the ordinance. For those who studied in the private network, but in a situation of economic fragility, a statement from the school became necessary for access to the exemption. We cannot say that this stimulus guarantees the student to attend higher education, if approved in the ENEM, but it is an advance when initiating a process of democratization of access to the test (PROUNI, 2016).

In 2003, the registration form for the ENEM began to record the socioeconomic data of its participants, enabling the expansion of the analysis on the grades, since, from that moment on, it was, and continues to be, possible to identify and compare the results of students with different socioeconomic-cultural profiles. This comparison is important in view of the necessary mapping of the educational performance of specific groups of society. The following year, PROUNI was created, allocating public funds for the financing of scholarships in private institutions of higher education and, in 2005, this program began to use the results of the ENEM to grant higher education scholarships in several private colleges in the country (PROUNI, 2016).

We noticed that the Federal Government spared no effort to put the ENEM in a position of prominence in Brazilian society. The ENEM test has increasingly become decisive for the future of those interested in attending higher education in Brazil. The federal government was increasingly concerned with enabling students to stay in higher education courses, using a series of mechanisms for the democratization of higher education in Brazil, in addition to increasing investments in public higher education (PROUNI, 2016).

This gain of importance of the National High School Exam, which presented itself as one of the paths for access to public funding programs and access to higher education caused changes in the structure of the exam and, with this, in 2009 , the federal government launched the so-called new ENEM:

The new ENEM test would bring the concrete possibility of establishing a positive relationship between high school and higher education, through a debate focused on the guidelines of the test. In this context, the proposal of the Ministry of Education is a call. A call to IFES to take the necessary role, as autonomous entities, of protagonists in the process of rethinking high school, discussing the relationship between contents required to enter higher education and skills that would be fundamental, both for future academic performance and for human education (BRASIL, 2009, p. 3).

To meet the new demands of the National High School Exam, the government created the SISU, a selection system that uses the ENEM grade for the entry of students into higher education. We assume here that the changes introduced in the ENEM to make the exam more accessible to students in a situation of socioeconomic fragility were fundamental for the democratization of higher education in
Brazil, but we recognize that there are a number of limits in this democratization, which, however, is not the focus of our study (PEROBA, 2017, p.120-128).

In 2013, INEP adopted the Item Response Theory (ITri), making the test score complex, since the proposed items, in addition to being considered "right" or "wrong", began to be analyzed through a software that commands the answers given to each item, considering their levels of difficulty and avoiding (or decreasing) the practice of "kicking" by respondents (DA SILVA, 2018, p.26).

Soon after the reformulation of the ENEM in 2009, the INEP's own report for the ENEM 2009-2010 highlighted another characteristic of the examination, quite important: the questions of the examination "start from contextualized problem situations, which allows to reduce the requirement of memorized contents, since the reasoning is valued (BRASIL, 2013, p.8)".

In this sense, the exam does not require the student to memorize data and facts, but rather an understanding of reasoning structures, social processes, natural phenomena and forms of communication, with an empathic view open to the diversity and sensitivity of respondents to Brazilian social problems, among them, racism. And in this regard, as a government strategy to combat racism in Brazil, it is important to highlight that, since 2003, the approval of law 10,639 , has made it mandatory to study Afro-Brazilian and African culture and history at all levels of basic education, as a cross-sectional theme, that is, present in all school disciplines.

In 2004, with the arrival of Gilberto Gil at the Ministry of Culture, a political-cultural movement began in the country, within which Brazilian culture began to settle on the notion of cultural diversity. In this sense, in 2004, the Secretariat of Identity and Cultural Diversity was created, through Decree No. 5,036 of April 7, 2004, according to which:

Art. 11. The Secretariat of Identity and Cultural Diversity is responsible for: I - promoting and supporting activities to encourage diversity and cultural exchange as a means of promoting citizenship, in charge of the Ministry; II - to monitor, together with the Secretariat of Institutional Articulation of Culture, the implementation of cultural policy forums, responsible for the articulation between the Ministry and the cultural community; and III - to subsidize the Secretariat of Cultural Policies in the process of formulating public policies in the cultural area related to the promotion of diversity and cultural exchange and the protection of copyright. (CIVIL HOUSE: 2004; in PEROBA, 2017).

In order to achieve its objectives more broadly, SIDC has related to other ministries in order to reinforce the need to promote cultural diversity and we believe that this relationship has occurred more closely with the Ministry of Education (CORREIA, 2013, p.53) since education is seen as a way to overcome racism. In this sense, the creation of the Secretariat of Identity and Cultural Diversity was a 
4 Andrade, T.H.V.C.; Queiroz, J.G.; Melo, E.H.S.; Lima, P.R.; Silva, P.E.S.; Silva, A.P.B.; Mélo, R.S.; Silva, M.V.A.; Silva, P.M.; Ancelmo, E. Twenty years of ethnic-racial relations in the National High School Exam - ENEM (1998-2018) ...

milestone in the possibility of democratization of culture in Brazil.

We believe that the creation of this secretariat was a clear signal from the government to the most diverse groups and institutions in Brazil, pointing to the need to value the Brazilian culture formed by Afro-Brazilians and indigenous peoples, which may have enabled an inclination of the ENEM to address these themes. Although these themes were addressed earlier in the ENEM tests, it is with law 10.639/03 and with SIDC that these themes gain more prominence in the test.

In 2016, the Temer government extinguished this secretariat and from then on, the number of issues related to racial issues was being reduced by about $50 \%$ until, in 2019 , there were no records of issues that addressed Afro-Brazilian or African culture in the 21 st edition of ENEM.

\subsection{Analysis of test questions}

We aimed to analyze the presence of questions about ethnic-racial relations, related to Afro-Brazilians and Africans, in all editions of the ENEM. For systematization and organization of this research, we have differentiated the questions into themes, namely: questions about slavery, issues demanded by black social movements and questions about African and Afro-Brazilian cultures. Our analytical focus was on the issues related to the History of Brazil. Before we go to the analysis of the questions, it is essential to make a consideration about the place and representativeness of these questions in the set of Exams. In the ENEM tests, from 1998 to 2018 (a total of 23 exams), we found thirty-one questions that deal with Afro-Brazilian or African culture; slavery and black social movements.

Although in the first test, in 1998, there was a question in this regard, it seemed to us to be occasional, given that only from 2004 there was another incidence. From 2011 to 2018 , in all editions of the race, the theme of racial ethnic relations related to Afro-Brazilians and Africans appeared, which demonstrates the relevance given to this theme in the tests.

In the two governments of President Lula (over 08 years) there was the incidence of 07 questions on this topic; in the governments of President Dilma Rousseff (in just 05 years2011-2016 -May/August) there were 17 issues; and even in the Temer government (2017/2016-2018) this theme was frequently discussed, totaling 06 questions, three exams.

To understand this lack of regularity of the approach to this very important theme, we opened two lines of research, the first was to seek the training of ministers of education in the period, which proved to be a fruitless line, because none of those who stayed long ahead of the MEC had training in Education, mostly they shared only the teaching career, higher education institutions.

The second line we opened to understand this phenomenon was the search for the presidents of INEP. We noticed that the presidents of INEP in the Lula, Dilma and Temer governments were academics of respect from various areas, but the profile more focused on education became a rule in the Dilma government and was maintained in the Temer government. We believe that these presidents more focused on education already recognize the importance of working on the theme of racial ethnic relations to build a fairer and more empathetic society. For spatial limitations, this theme cannot be worked on in this text.

The most common issues about ethnic racial relations, in the ENEM tests throughout the period, being on average $60 \%$ of the analyzed issues, were slavery and its abolition process in Brazil. In order to analyze the issues, it is essential to understand in which conception of slavery and the abolition of the issues of the ENEM are included.

In Brazilian historiography the slave (in the singular, but considering the set of workers submitted to this type of compulsory work) was already considered as the "father John" (characters of American literature), who was an example of slave "good", "suffered", meek and at the mercy of the evils of his masters. In addition to this paradigm, Brazilian historiography has already treated enslaved subjects as warriors, such as Zombies (FREITAS, 1978). In addition to "suffering saints" and "ruthless warriors", there was an important part of historiography that considered slaves reified people, made "things", who acted and thought only of the limit of being goods (AZEVEDO, 2010). And finally, there is a vigorous historiography, whose works are already exceeding thirty years, according to which enslaved people may have had specific behaviors such as "suffered", such as "warriors" or as "things", but who, structurally, "negotiated" with slavery within the limits of their possibilities, seeking the best survival strategies for themselves and their own (CHALHOUB, 1990).

This historiography, more recent, therefore, is already a historiography consolidated in Brazilian science, and comprises the "being slave" as an active agent in the process of slavery/abolition: a slave who negotiates with his masters, who enters justice, who, even without knowing how to read, has access, through listening, to a series of knowledge, (AZEVEDO, 2010).

The second question that emerges from this perspective is to understand whether the ENEM problematizes the issue of race and whether the evidence contributes to a non-racist view of society.

In this new historiography, the economicist view of slavery gave way to considerations about the slave culture, for cultural exchanges, for slave politics, the various meanings of the body languages of struggle (capoeira), festive (the entrudo, Maracatus), or of disciplinary practices (escape). That is, if you think and study slavery through the prism of freedom, slaves gain humanity, have emerged as protagonists of their stories.

The new historiography demonstrated that enslaved people were not "poor", but survivors struggling, in a harsh reality, to achieve a greater goal, their personal freedom, their families and their bonds of affection and the preservation of their culture. An important name in this debate is the UNICAMP historian Robert Slenes, who studied the formation of slave families and the networks of mutual support that formed around these families, demonstrating 
that the slave was not an Inept, but was able to form networks of mutual support for the preservation of their culture and for their safety, for instance.

The author himself pointed out that the slave family "probably helped many captives to preserve their identity and effectively deal with the psychological pressures of slavery. At the same time, however, it provided the owners of the plantations with a powerful instrument of social control." We noticed that the author revolutionized the vision of slavery, emphasizing the daily life of slave quarters (the maximum place of manor oppression), their organizations, negotiations and arrangements (SLENES, 1976, p.414).

The abolitionist approach was surpassed, in which the leading role fell on those who, by exercising the places of power in society, put their names in the processes of abolition, that is, the magistrates, the labor inspectors. These characters no longer fit the exclusive protagonism, but rather shared with various groups and individuals who fought, daily, while the slavery lasted, against it.

Secreto will reveal to us that the contributions of the new works are mainly "in the study of urban slavery, on social practices of compatriot, family and slave demographics, on economic and identity practices, slave resistance" (2016, p.3). So, what we seek in the editions of the ENEM test, especially after 2009, when we have a greater number of questions, are exactly these themes, addressed in order to place the slave as an active agent, problematizing the notion of race and breaking with the racialistic views of the nineteenth and early twentieth centuries.

The "slave-thing" emerged as a scathing criticism of the tradition that defended the nonviolent character of slavery in Brazil, whose great exponent was Gilberto Freire and his work, in particular, Casa grande and Senzala (FREIRE, 1992). The "slave-thing" was one who was placed in a situation of domination so rigorous, so hard and so alienating, that he was unable to perform human actions, unable to resist, to think for himself. That is, he was not considered an agent of society, but he was exactly what you wanted him to be (CARDOSO, 1962).

As "things" they reproduced exactly to the expectations of that society, that is, they had no action in relation to violence on the basis of which they were treated. This historiography was more related to a type of Marxist vision that gained a body in the late 1960s, represented by the socalled São Paulo school of Florestan Fernandes (advisor to Fernando Henrique Cardoso). Moreover, this vision contributed to the creation of a second myth, derived from the myth of the "slave-thing", which is the myth of the "rebel slave".

The "rebel slave" was considered a threat to society, as he joined a radical uprising, which made him available to humanity's most desperate impulses. We went from a dehumanized slave, who had no power to negotiate, nor observation, totally attached to the system, to another who sought, irrationally, to violently pierce the system and escape its moorings. But the new historiography, cited earlier, presented a slave as an agent capable of creating symbols in his own world, able to act with subtleties against the oppression of his masters and the State, using the limits of the slave system and its laws. Sidney Chalhoub, who worked with the "actions of freedom" filed on behalf of slaves, told us that it was "always difficult to know if the slaves' allegations were true, and everything is further complicated because the struggle of the captives for "alforria" usually appears in a broader fabric of relations and conflicts" (CHALHOUB, 1990, p.111).

Ângela de Castro Gomes, in the essay entitled "Social question and historiography in Brazil post-1980: notes for a debate" presented us with the new ways of thinking about slave labor and highlighted that the slave's own suicide must be politicized, because all action of the captives was political, in search of their freedom, in search of ways to resist. The author reminds us that actions in the world of work reverberate directly in the social and political field, thus presenting us with the need to look at slavery and abolition in the most diverse sectors of society.

The new historiography of slavery has been proposing for years that we take different views on history, to understand the social relations between the (supposedly) "dominated" and their (also supposedly) "dominators", far from a dichotomy or generalizations. People in situations of dependency, whatever it is, do not follow their lives convinced of their inferiority (always political and economically constructed), seek mechanisms that sometimes allow them to pierce the system and overcome its limitations.

Then, new concepts emerged in history, concepts that increased the analytical possibility in depth and surface of the historicity of the long-distance institution of slavery: concepts such as ethnicity, pact, resistance, negotiation and political culture enhanced studies on slavery. The processes are no longer understood within a linearity and predictability, the story is not approached in a tautological way, but rather open to twists, by exceptionality, by the specialty. That is, it is not possible to determine how all slaves resisted, for example, but it is possible to perceive ruptures and continuities in the different ways of resisting, in different places. In other words, one no longer thinks in a generalist or generalizing way.

However, other experiences speak, not only those in which enslaved people and their descendants were framed by the agents of power. Ângela de Castro Gomes speaks of "ritual ceremonies, written texts and manifestations of resistance" (2004, p.161) as new places for the study of the history of Afro-Brazilians and Africans. In this sense, we see the "Entrudo" (a carnival manifestation of the nineteenth century) as an experience re signified by slaves and their descendants, understood as agents and builders of their history. In the ENEM, this theme appeared twice, in 2008 (in question 38) and in 2013 (in question 15), as we can see respectively in figures 1 and 2 : 
6 Andrade, T.H.V.C.; Queiroz, J.G.; Melo, E.H.S.; Lima, P.R.; Silva, P.E.S.; Silva, A.P.B.; Mélo, R.S.; Silva, M.V.A.; Silva, P.M.; Ancelmo, E. Twenty years of ethnic-racial relations in the National High School Exam - ENEM (1998-2018) ...

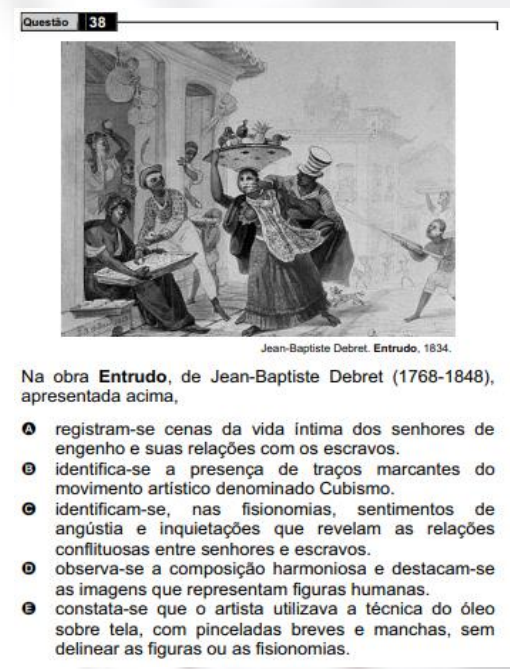

Figure 1. ENEM test, 2008 edition, yellow proof, question 38. Source: INEP

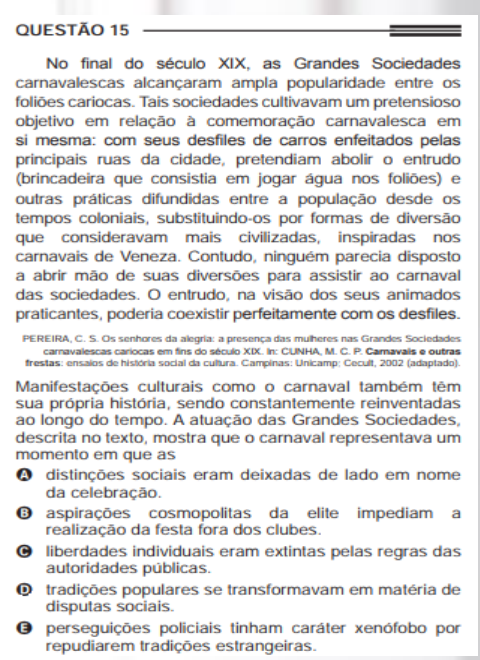

Figure 2. Proof of the ENEM, 2013 edition, yellow proof, question 15 . Source: INEP

In both questions, the template is the letter D. Entrudo was a part of the carnival party, celebrated both by free people, as well as by those in a situation of slavery, in which a subversion of the social order and cultural values could occur, with atabaques in the streets and people with the faces of flour and water, for instance. However, when we observe the questions presented in the ENEM about this feast, it is contemplated that the meanings (these studied by the new historiography of slavery) were completely emptied in the question of 2008 and disregarded in the question of 2013.

Although the issue of 2013 already presents a view of social conflict in culture, it does not problematize this issue. The answer is obvious, black culture or popular culture are just accessory themes to the issue. In this sense, it seems to us that the ENEM did not require a historiographical understanding of the contributions of Afro-Brazilians and Africans to the modifications of cultural expressions coming from Portugal, or to their resignifications in Brazil. The examination could politicize the parties, demonstrating that they were not "innocent" actions, that inside, the agents, although smiling, expressed their knowledge and discontent with the power relations and socially experienced tensions. Five questions were chosen to analyze the theme of slavery in the ENEM. This is one of the most recurring themes in the editions of the ENEM, according to our survey, and we chose four questions to demonstrate how this theme has been addressed in the tests, not over the years.

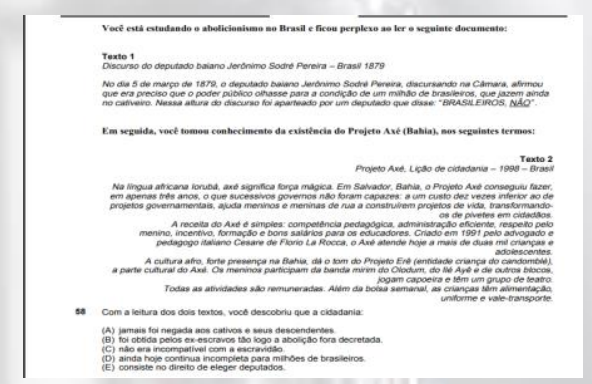

Figure 3. Proof of the ENEM, edition of 1998, yellow proof, question 58. Source: INEP

In the first edition of the test, from 1998, we observed its question no. 58, whose template is the letter D (Figure 3). The debate that the question proposes is about the idea of citizenship and slavery, that is, slavery had negative repercussions for citizenship in the long duration. These consequences can be felt in our society so unequal on racial issues, to this day. What draws attention to this issue is that it is not necessary to trigger any historical knowledge about slavery in Brazil to answer it. That is, the question first launched in ENEM, in a history test, about slavery in Brazil, does not require any specific historical knowledge on the subject, but only that the student knows how to interpret texts. At that time, the ENEM was not used for admission to higher education, only as an exam to "check" the learning in high school, moreover, the ENEM was not a proof of national proportions, and perhaps these reasons generated some relaxation in the questions of the test. Following the chosen questions, let's go to the next one.

In Figure 4, we observe question 18 of the year 2007 and the feedback of the question is the letter $\mathrm{D}$. This question presents itself as irrelevant for the construction of a nonracist thought, because it does not require the student even an empathy with the abolitionist cause, which is treated as a linear and uninterrupted succession of facts. The answer suggests that abolition was carried out simply through laws, thus placing the process of abolition (experienced in 04 distinct laws and separated in time for almost 50 years, characterizing the emancipationist path taken by Brazil) as something distanced from the struggles of free and enslaved people, a view that had been refuted by historiography since the 1980 s. 


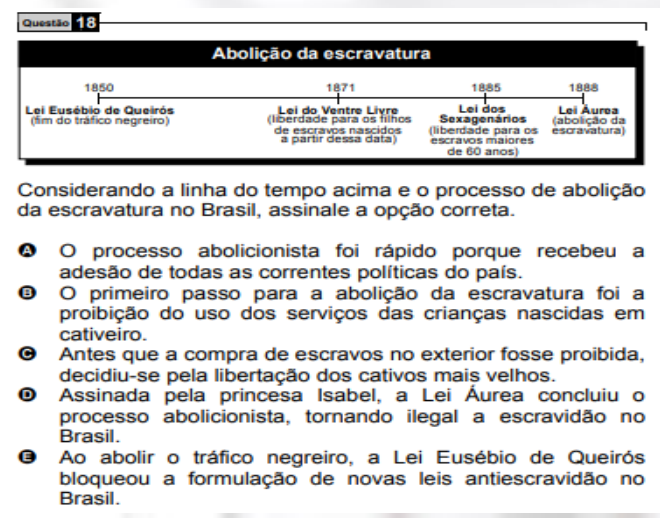

Figure 4. ENEM test, 2007 edition, yellow proof, question 18. Source: INEP

The second question chosen, which is next to, no. 39 (Figure 5) is from the year 2008 and has as its feedback the letter A. This, in turn, repeats the view of the "slave-thing" present in the first question we present. The words of the abolitionist parliamentarian (white and rich) Joaquim Nabuco, reiterates the view that enslaved blacks had no participation in the process that culminated in the abolition.

In his view, parliamentarians, educated people, owners, free abolitionists, statesmen and the royal family participated in the process. The thousands of free, poor (of all colors) and enslaved people in the different regions of the country did not participate in anything. The view presented by the two questions is not only conservative, but also antihistoriographical and inadequate for the advancement of overcoming racism in Brazilian society and, in this sense, does not dialogue with the proposals of the political project of the governments of the Workers' Party (PT).

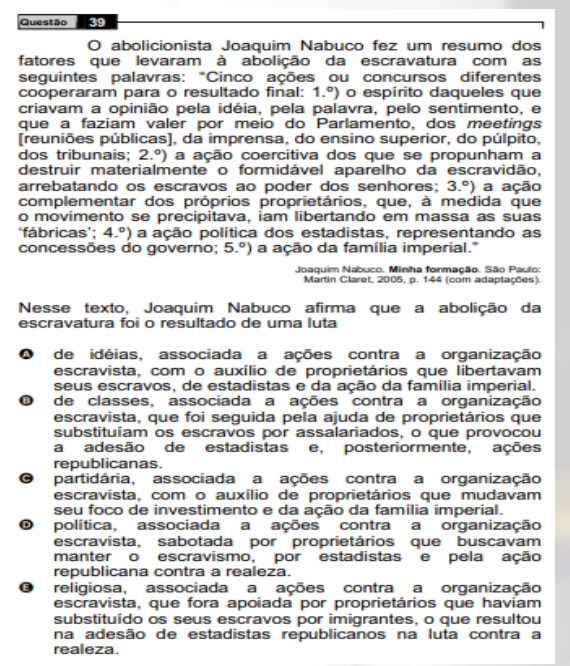

Figure 5. Proof of the ENEM, 2008 edition, yellow proof, question 39. Source: INEP.

It would be up to the social struggles and political clashes that preceded the enactment of the laws and their consequences. It would be necessary to consider the struggles of the different subjects and groups (free and slaves), politicians and civil society, organized or not, nobles and commoners, to end slavery.

The question chosen is one of 2013, question 12 (Figure 6 ) whose template is the letter $C$. This question walked in the same direction as the previous ones, and also pointed to a legal route of action against slavery. Although the question does not problematize what we presented earlier, she pointed again to a thought of Joaquim Nabuco, who apparently believed and defended that it was up to the free population the process of black liberation.

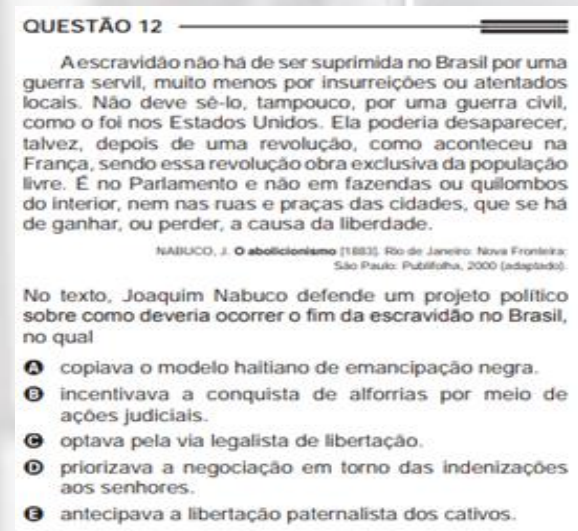

Figure 6. Proof of the ENEM, 2013 edition, yellow proof, question 12. Source: INEP.

The question could question whether or not quilombos were places of freedom in fact. Problematizing the "visions of freedom" in the quilombos would bring the question of the interpretative propositions of this new historiography of slavery and break with the myth that "freedom" could only be experienced "outside society", by those who fled, as if only the quilombos were as places of freedom, a fact that has also been surpassed by historiography, as pointed out by Flávio Gomes in his book "Mocambos and Quilombos: a history of black in Brazil", in which the author "criticizes the approaches that conceive a romanticized view of quilombos as isolated, as a reproduction of Africa. He draws attention to the fact that Brazilian mocambos/quilombos were adapted to the specific conditions, in the case of Brazil" (MATOS; EUGENIO, 2018, p.233).

We can see that the elaboration of the questions has gone through a historiographical approach that has already been overcome and is currently combated. Considering that the choice of the historical approach on a theme is always political-ideological, in addition to dealing with scientific and pedagogical interest, we affirm that these issues cannot be seen in the list of issues that combat racism and give prominence to black characters in the process of slavery.

The last question chosen was from the year 2016, no. 36 (Figure 7) and the feedback is the letter C. We believe that the proof of the ENEM could approach historiography bringing texts of freedom actions, in which slaves were able to exercise their power of negotiation, argumentation and proved to be active (and even creative) in their liberation processes. In this sense, we have the work of Sidney Chalhoub who demonstrated the close relationship between 
8 Andrade, T.H.V.C.; Queiroz, J.G.; Melo, E.H.S.; Lima, P.R.; Silva, P.E.S.; Silva, A.P.B.; Mélo, R.S.; Silva, M.V.A.; Silva, P.M.; Ancelmo, E. Twenty years of ethnic-racial relations in the National High School Exam - ENEM (1998-2018) ...

the actions of slaves, based on the "visions of freedom" they built in their situation of captivity, and the results of the crisis of slavery (MARQUESE, 2013, p.233).

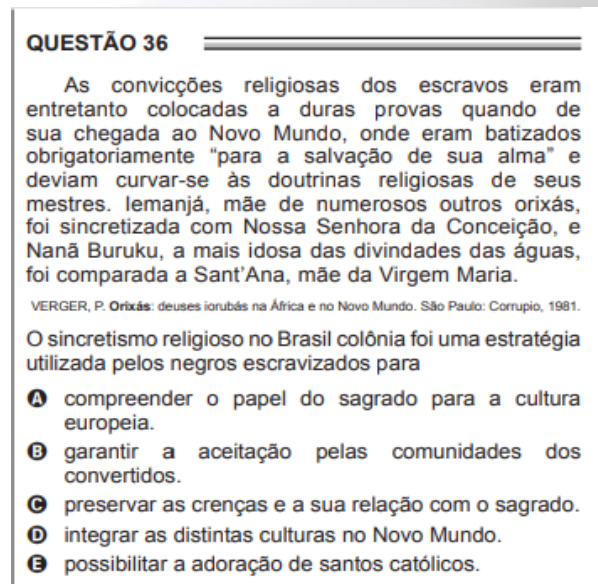

Figure 7. Proof of the ENEM, edition dand2016, yellow proof, question 36. Source: INEP.

However, it is worth noting that the ENEM did not adhere, at any time, from 1998-2018, to the perspective of denying/erasing the stigma of slavery linked to color and class. Thus, the examination presents itself as if in the middle of the road, does not seek to erase the cursed inheritance of slavery, but does not dialogue with the most recent historiography that demonstrates the protagonist of black agents.

Nilma Lino, in the book called "The black movement educator", invited us to understand african and afro-Brazilian history, which was sometimes erased, sometimes hidden, sometimes viewed in a stereotyped way, by other lenses. This invitation was made from the action of a black movement that fights for an education that presented "its version" of history (explaining that historical narratives are objects of struggle), which valued "black identities", which broke with limiting views on Afro-Brazilians and Africans.

The black movement has occupied the field of education by seeing, in this field, the possibility of overcoming racism by empowerment, revisitation and rescue (a word that historians do not use) of the roots of black people in Brazil. The idea is to bring to school the contributions, of struggles, of black movements for the formation of Brazil and its identities. What the author calls "knowledge born of struggle" (2017, p.9) we perceive in moments of recognition of this struggle, such as the approval of law 10.639/03 that made mandatory the teaching of Afro-Brazilian and African history and culture in public and private schools, at the elementary and middle levels throughout Brazil.

The author argues that the black movement produces emancipatory knowledge for blacks, because these knowledges seek to present the contribution "afro" in the formation of Brazilian society. For her, social movements are "the producers and articulators of knowledge constructed by the non-hegemonic and hegemonic groups of our society" (2017, p.16). It considers that knowledge coming from the working class to the working class, and speaking of this class is rather a knowledge that interests, liberates and promotes the construction of free identities. These disputes can be felt in the curricula, which is one of the places of clash between the different ways of seeing and describing the world, among them, the scientific ones (MATOS, 2013).

The curriculum is the place of legitimization of a particular worldview, which will be transmitted, debated and matured in school. The curriculum is not thought of as an innocent artifact, but as an instrument of the powers in force or in struggle (SILVA, 2010).

The curricular disputes have already tried to organize knowledge in "boxes", determining what should be taught in schools; and began to highlight, more recently, the importance of students' knowledge, in order to scientifically develop children, so that they could develop a desirable adult personality. The school curriculum came to be perceived as something that was not "transcendent and timeless", but rather implied in power relations, which authorize certain particular and interested social views, besides producing social identities, no less interested. Within our study of the issues on ethnic-racial relations in the ENEM, we see the need to think about the questions about identity within the critical theories of the curriculum that question what kind of identities are intended to be formed with certain curricula, because it is understood that the curriculum is a clipping and, therefore, always defends a determined point of view.

According to Christian Laville (1999) there is always a game of forces around the history curriculum. These forces focus on the narratives that are constructed, based, falsely, according to the author, on the illusion that history is capable of shaping minds, that is, shaping thoughts for what a group, the one who chose the curriculum, determined.

This does not mean that it is always the State that exercises power over the curriculum in order to form a position that favors it, often other movements exert influence over the curriculum. We say this, corroborating the idea presented by the author by saying that "the historical narrative can also be seen as a power takeover by groups without power" (LAVILLE, 1999, p.134).

Laville's observation reminds us of the struggle of the black movement to have its history seen from another point of view. The changes in the curriculum, especially after the passage of law 10.639/03, as the law itself, served to give voice to a group that had no power, that were silenced by history, blacks. This seizure was the result of the struggle of the black movement, for the right to memory, history and identity.

These advances achieved by social movements are important to democratize the teaching of history, as it opens the possibility of hearing different and sub-alternated voices in the predominant historical narratives. However, we do not believe that the struggles of social movements should guide school curricula, however, we cannot deny the influence of these movements in school, since the school must always maintain dialogue with civil society.

The school as a place of debate of scientific knowledge must be open to the demands of social movements, within the constitutional principles, that is, in everything that exalts 
democracy, human rights and the exercise of citizenship. However, we must pay to some claims that are the fruit of social movements, but which, in our view, do not fit in school, for example, the "School without party".

This project aimed to silence voices, police teachers and prevent the principles of freedom of chair and opinion, different from projects such as those that generated laws $10.639 / 03$ and $11.645 / 08$, which sought to democratize the voices heard in the school, which sought to include and debate. People don't need school to be what they are, but the school plays a key role in knowing itself and its cultural, economic and social roots.

The traditional curriculum of school history is one, according to which there was no possibility of cultural resignifications (from the historicity of slavery) by slaves and their masters. This curriculum reduces the slave to passivity and places you as superior and unattainable.

To work on the issues of social movement and struggle around what should be taught and learned about ethnic-racial issues in high school, we chose four ENEM issues. The first question chosen is question 16 , from the year 2007, whose template is the letter D (Figure 8).

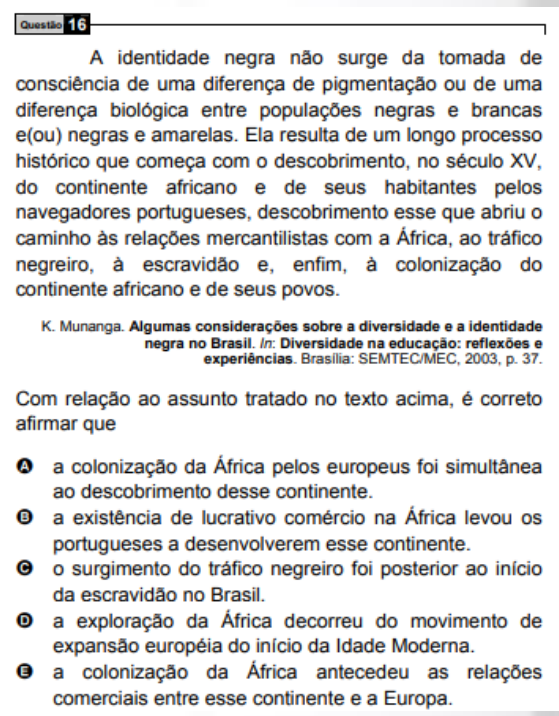

Figure 8. Proof of the ENEM, edition dand2007, yellow proof, question 16. Source: INEP.

This question does not require the student to reflect on the formation of a black identity, as opposed to a European identity that tries at all times to establish itself as superior. In our assessment, Kabenguele Munanga, the author used by the ENEM issue, wanted to exempt Africa and Africans from the barbarism of slavery that they themselves invented and sustained, and not only Europeans.

A certain historiography points to the enslavement and the slave trade as civilizational projects of the African continent. Manolo Florentino's book, entitled "On black shores", will point us to important issues in this regard. From a voluminous research, the author demonstrates that slavery was a civilizational project of the African continent, which does not mean that the European has not actively participated in this process, by making slavery an extremely lucrative trade outside the African continent.

The issue does not present a broad historiographical debate, apparently it focuses on a somewhat militant view as that of Kabenguele. However, this issue presents itself as an advance in the ENEM, because it is the first of this theme to appear, which means an advance in the presence of the AfroBrazilian and African theme in the test.

On this subject, the second question we chose was question 32 of the 2011test (Figure 9), whose feedback was the letter E, as shown above. This question places the importance of the demands of social movements for the formation of a society that recognizes its diversity and values it. This question imposes the validity of the legislation to which it refers, because it is necessary to observe that no educational law is mentioned in any evidence of basic education, as occurred in this, regarding the need to study the "blacks" (Africans and Brazilians) and their contributions to Brazilian society.

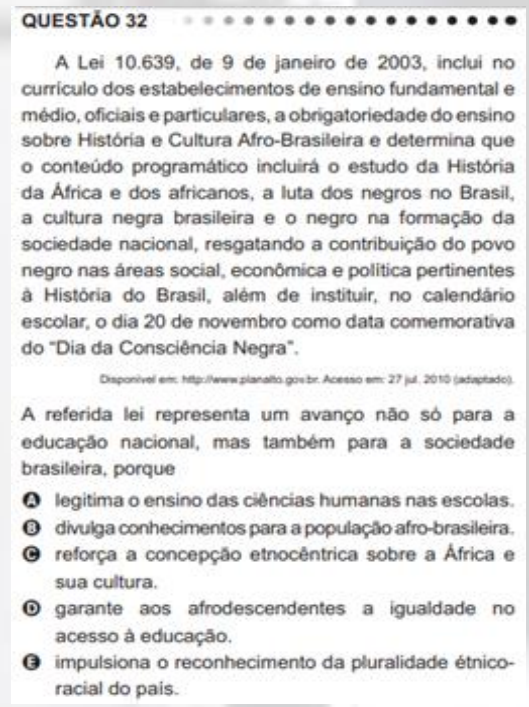

Figure 9. Proof of the ENEM, edition dand2011, yellow proof, question 32. Source: INEP.

The question is extremely simple and does not require the student a historiographical knowledge about the consequences of slavery for the descendants of the enslaved, that is, the question is much more related to an interpretation of text and an updated attitude towards the subject, than to a specific historical knowledge about the consequences of slavery in the long duration.

The third question we chose to work on was question 09, from the year 2012, (Figure 10), whose template was the letter A. We observe the question below. 
10 Andrade, T.H.V.C.; Queiroz, J.G.; Melo, E.H.S.; Lima, P.R.; Silva, P.E.S.; Silva, A.P.B.; Mélo, R.S.; Silva, M.V.A.; Silva, P.M.; Ancelmo, E. Twenty years of ethnic-racial relations in the National High School Exam - ENEM (1998-2018) ...

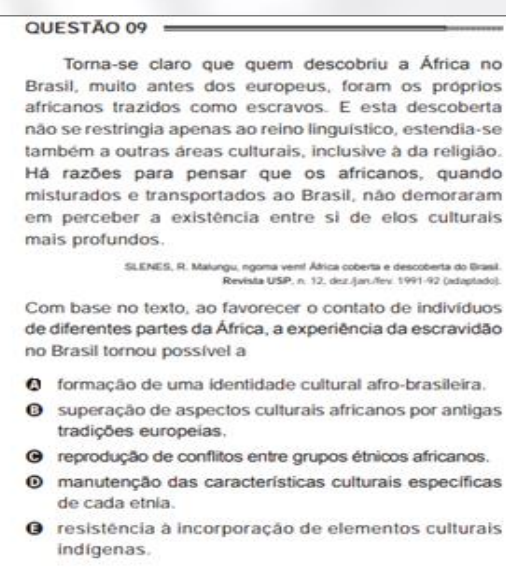

Figure 10. Proof of the ENEM, edition dand2012, yellow proof, question 09 . Source: INEP.

This issue is concerned with the formation of an AfroBrazilian identity. We consider this formation fundamental because it indicates that, just as Africans had their customs modified by reason of slavery, they also modified the customs that were pre-existing in Brazil. Historiography points out that Africans, despite their differences (very serious and warlike), have been (including, religiously) in the suffering of transatlantic crossing and the experience of slavery; creating something new, an Afro-Brazilian identity, which, as we know, is not monolithic (SLENES, 2011).

The text presented by the question is by historian Robert Slenes and presents to us the possibility of cultural exchange between enslaved and white or indigenous Africans, presenting Brazilian culture as heterogeneous, a plural culture, in which it makes no sense to speak of culture solely "black", because Brazil does not have, in a well determined way, what is a black culture and what is not. failure" of the process of rooting Africans and their descendants in Brazil with the loss of their "true" traditions, on the contrary. It is the reinvention of traditions, the re-creation of negotiated cultural practices, in a context of conflicts and collaborations experienced by enslaved and free people, of all colors and many different nationalities, in the Brazilian slave reality.

The last question chosen on this subject was question 34, from the 2014 test (Figure 11), whose template was letter C.

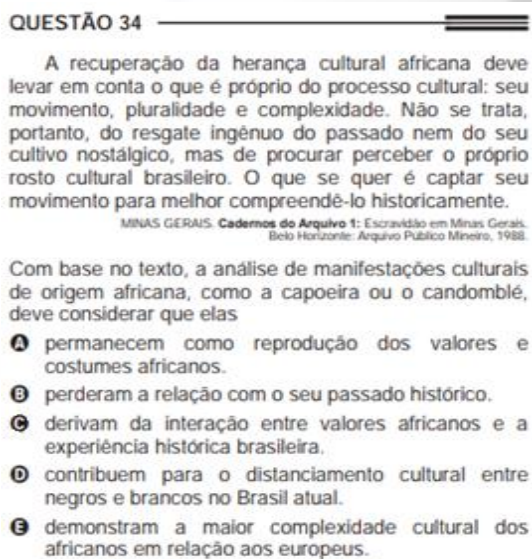

Figure 11. Proof of the ENEM, edition 2014, yellow proof, question 34. Source: INEP.
When analyzing it, we observed that the National High School Exam comes, throughout its editions, as we stated earlier, modifying the approaches on the importance of the demands of social movements, especially the black movement, and that the struggles for recognition of an AfroBrazilian culture are increasingly present in the exam.

We noticed that the questions of the ENEM on the subject dealt with here have become increasingly complex over the years and have increasingly pointed to the complexity of Afro-Brazilian culture. We affirm, observing the issues we present here that are, in our view, the issues that can best represent how the ENEM includes the agendas of social movements and Afro-Brazilian and African culture.

\section{Conclusions}

The analysis of several ENEM questions related to the black ethnic-racial agenda, over these twenty years of evidence, allows us to understand some of the dynamics of this examination without, however, being possible, at this moment, to exhaust the theme. The considerations we have reached put the National High School Exam in check as to its ability to be an evaluative instrument of the themes that we propose to analyze.

However, in this text we are unable to indicate that there is a problem with the evaluation instrument, that is, the proof; or if it is only with regard to the themes of ethnic-racial relations that the issues present a political and historiographical disdain. Throughout the text, we present that the questions of the ENEM are highlighted in the new historiography, often bringing outdated questions.

We were not indicating that there is only one truth, that it would be that of the new historiography, that the examination should follow, but to indicate the contradiction of the evidence when using a historiography overcome and fought today, when it has as its guideline the use of the current paradigms of scientific and artistic production, as previously indicated.

We understand the ENEM test as one of the most important formative elements of education in Brazil at this time and we suspect that this evaluation influences the most diverse levels of education, but especially in high school.

Education for experiencing positive ethnic-racial relations between Afro-Brazilians and Africans and other groups is, in our conception, a theme of fundamental importance for overcoming a racist and unequal society that naturalized racial inequality and often denies slavery and its consequences.

We realized that, in several themes, the ENEM has come a long way and presents a vision committed to breaking stereotypes and paradigms, a vision that can help in overcoming the way our society sees its identity and history. However, in some themes, and here we talk specifically about slavery, the questions of the Exam still need to adapt to the new historiography, as we have already indicated.

We speak this with some concern, because what we call a new historiography on slavery are works already consolidated, which were written and debated in the 1980 s 
and 1990s, which presents a serious scientific delay in the elaboration of issues in this sense.

We realized that the history of Afro-Brazilian peoples was reduced to the experience of slavery, which, although fundamental, does not exhaust or explain all aspects of the complexity of social, political and economic relations that permeate the country's current history and the experience of Afro-Brazilian populations. The emergence of issues that talk about black culture and protagonism demonstrate the emergence of a new historical perspective on these peoples gaining space in the ENEM and, consequently (hopefully), in schools.

ENEM issues are repeatedly concealing the struggles of social movements and slaves (when referring to the times of slavery) to obtain their rights. It is perceived that, even with the advances presented, the evidence still denies the proper protagonism to the slaved, ex-slaved, their descents and social movements, especially the black movement.

It was also clear, in our view, that many issues, including the most current ones, do not yet require a specific historical knowledge on the central theme addressed, often the issues are only of interpretation of texts.

This gain in the importance of these movements and the arrival of their agendas at school is, in our view, a positive perspective that society can overcome its myths and its prejudices. We believe that the ENEM can also be another strategy for overcoming racism in Brazil to be intensely discussed and promoted in basic education.

\section{References}

[1] Proposta à Associação Nacional dos Dirigentes das Instituições Federais de Ensino Superior. Brasília: Ministério da Educação (MEC). Instituto Nacional de Estudos e Pesquisas Educacionais Anísio Teixeira (INEP), 2009.

[2] Relatório de gestão, 2000. Brasília: Ministério da Educação (MEC). Instituto Nacional de Estudos e Pesquisas Educacionais Anísio Teixeira (INEP), 2001.

[3] BRASIL, Instituto Nacional de Estudos e Pesquisas Educacionais Anísio Teixeira. Exame Nacional do Ensino Médio (ENEM): relatório pedagógico 2009-2010 / Instituto Nacional de Estudos e Pesquisas Educacionais Anísio Teixeira. - Brasília: O Instituto, 2013. 133.

[4] CARDOSO, Fernando Henrique. Capitalismo e escravidão no Brasil meridional: o negro na sociedade escravocrata do Rio Grande do Sul. São Paulo, Editora Difusão Europeia do livro, 1962.

[5] CARVALHO, Marcus J. M. de. Liberdade: rotinas e rupturas do escravismo. Recife, 1822 - 1850. Editora universitária da UFPE, 1998

[6] CHALHOUB, Sidney. Visões da Liberdade: uma história das últimas décadas da escravidão na corte. São Paulo, Companhia das Letras, 1990.

[7] CORREIA, Ana Maria Amorim. Diversidade cultural no governo Lula: um olhar para a Secretaria de Identidade e
Diversidade Cultural / Ana Maria Amorim Correia. 2013. 128 f.: il. Dissertação (mestrado) UFBA.

[8] DA SILVA, Tatiana; BARROSO, Marta F.; RUBINI, Gustavo. Dificuldades na aprendizagem de Física sob a ótica dos resultados do Enem. Rev. Bras. Ensino Fís. [online]. 2018, vol.40, n.4, e4402. Epub June 18, 2018. ISSN 1806-9126. http://dx.doi.org/10.1590/18069126-rbef-2018-0059.

[9] FLORENTINO, Manolo. Em costas negras: Uma história do tráfico de escravos entre a África e o Rio de Janeiro. São Paulo, Companhia das Letras, 1997.

[10] FONSECA, Thais Nívia. História \& ensino de História. $3^{\circ} \mathrm{ed}$, Belo Horizonte, autêntica, 2011.

[11] FREIRE, Gilberto. Casa-grande e Senzala. Rio de Janeiro: Editora Record, 1992.

[12] GOMES, Ângela de Castro. Questão social e historiografia no Brasil do pós-1980: notas para um debate. Estudos históricos, Rio de Janeiro, $\mathrm{n}^{\circ} 34$, jul/dez de 2004, p.157-186.

[13] GOMES, Nilma Lino. O movimento Negro Educador: Saberes Construídos na luta por emancipação. Petrópolis, Rio de Janeiro, Vozes, 2017.

[14] GUIMARÃES, Antônio Sérgio Alfredo; HUNTLEY, Lynn (Orgs.). Tirando a Máscara: ensaios sobre o racismo no Brasil. São Paulo: Paz e Terra, 2000.

[15] INSTITUTO NACIONAL DE ESTUDOS E PESQUISAS EDUCACIONAIS ANÍSIO TEIXEIRA (INEP). Conheça o Inep. 2015. Disponível em: Acesso em: 04 jul. 2019.

[16] LAVILLE, Christian. A guerra das narrativas: debates e ilusões em torno do ensino de História. Dossiê: Identidades/Alteridades, Rev. Bras. Hist. 19 (38), 1999.

[17] MARQUESE, Rafael de Bivar. As desventuras de um conceito: capitalismo histórico e a historiografia sobre a escravidão brasileira. Revista de história São Paulo, $\mathrm{n}^{\circ}$ 169, p. 223-253, julho / dezembro de 2013.

[18] MATOS, Wesley \& EUGENIO, Bendito. Resenha sobre GOMES, Flávio dos Santos. Mocambos e Quilombos: uma história do campesinato negro no Brasil. São Paulo: Ed. Claro Enigma, 2015. In: Fronteiras: Revista de História, Dourados, MS, v. 20, n. 35, p. 232 - 237 -jan. / jun. 2018.

[19] MATTOS, Marcelo Badaró. A classe trabalhadora: uma abordagem contemporânea à luz do materialismo histórico. Revista outubro n.21 $2^{\circ}$ semestre 2013, p.81117.

[20] PEREIRA, Thiago Ingrassia \& DA SILVA, Luís Fernando Santos, As políticas públicas do ensino superior no governo lula: expansão ou democratização? Revista Debates, Porto Alegre, v.4, n.2, p. 10-31, Jul.-dez. 2010 .

[21] PEROBA, Keila. Exame Nacional do Ensino Médio (ENEM) e suas implicações no contexto escolar: o caso da escola estadual de ensino médio "Emir de Macedo Gomes" em Linhares - ES. Dissertação (Mestrado em Ensino na Educação Básica), 2017, 258f. 
12 Andrade, T.H.V.C.; Queiroz, J.G.; Melo, E.H.S.; Lima, P.R.; Silva, P.E.S.; Silva, A.P.B.; Mélo, R.S.; Silva, M.V.A.; Silva, P.M.; Ancelmo, E. Twenty years of ethnic-racial relations in the National High School Exam - ENEM (1998-2018) ...

[22] REIS, João José e SILVA, Eduardo. Negociações e Conflitos: a resistência negra no Brasil escravista. São Paulo: Companhia das Letras, 1989.

[23] SAVIANI, Demerval. Educação brasileira: estrutura e sistema. $11^{\circ}$ ed. Revisada. Campinas, São Paulo, Autores associados, 2012, p.63.

[24] SILVA, Tomaz Tadeu da. Documentos de Identidade: Uma Introdução às Teorias de Currículo. $3^{\circ}$ Edição. Editora Autêntica. 2010

[25] SLENES, Robert Wayne Andrew. Na senzala uma flor: Esperanças e Recordações da Família Escrava (Brasil Sudeste, Século XIX), Rio de Janeiro, Nova Fronteira, 1999.

[26] THOMPSON, Edward. A formação da classe operária inglesa, v. I, A árvore da liberdade. Rio de Janeiro: Paz e Terra, 1987.

[27] THOMPSON, Edward. A História Vista de Baixo. In: THOMPSON, E. P. As peculiaridades dos ingleses e outros artigos. São Paulo: UNICAMP, 2001. p.185-201. 